\title{
Studies on prevalence of cestode parasites in fresh water fish, Channa punctatus from Meerut (Uttarpradesh) India
}

\author{
Bindu Sharma \\ Department of Zoology D.N.P.G. College Meerut (U.P.) INDIA \\ E-mail: bindu2502@ rediffmail.com \\ Received: February 16, 2016; Revised received: March 3, 2016; Accepted: March 23, 2016
}

\begin{abstract}
The present investigation deals with the prevalence of three cestode parasites viz. Lytocestus sp., Proteocephalus sp. and Gangesia sp. collected from the intestine of a freshwater fish Channa punctatus in different blocks of Meerut region (U.P.) India during June, 2014 to May, 2015. A total of 125 parasites were collected throughout the year. The high incidence of infection of all these species Lytocestus sp., Proteocephalus sp., Gangesia sp. was recorded in summer season $\quad(70.83 \%, 77.27 \%$ abd $72 \%$ respectively) followed by winter season $(63.63 \%, 57.89 \%$ abd $52.38 \%$ respectively) whereas infection was low in monsoon season $(36.84 \%, 27.78 \%$ abd $23.52 \%$ respectively). The present study clearly indicates that the intensity of infection throughout the year was found highest in summer season followed by winter and lowest in monsoon. Findings show that beginning of the breeding period, feeding habitat, presence of intermediate host and environmental factors are influencing the seasonality of cestode parasitic infection.
\end{abstract}

Keywords: Prevalence, parasite, cestode, Channa punctatus, Lytocestus, Proteocephalus, Gangesia

\section{INTRODUCTION}

Often referred to as "rich food for poor people," fish provides essential nourishment, especially quality proteins and fats, vitamins and minerals. People involved in fisheries, aquaculture and fish trade, fish are a source of income. It is man's most important single source of high-quality protein, providing $\sim 16 \%$ of the animal protein consumed by the world's population. According to the Food and Agriculture Organization of the United Nations, nowadays, aquaculture makes a major contribution to human nutrition (Chakraborty $e t$ al., 2013). Since human utilizes these fishes, it is important that they should be healthy and free of infection. Channa punctatus (Bloch) has been gaining importance not only as the most common staple food fish but also as an aquarium fish (Saikia et al., 2012). Although, over the last 10 years, its population has undergone a steady decline due to overexploitation, loss of habitat, pollution as well as destructive fishing. According to IUCN status, it has been listed among the 66 LR-nt fish species in India (Molur and Walker, 1998). The fish is well known for its taste, high nutritive value and medicinal qualities and is recommended as a diet during convalescence (Haniffa et al., 2004).

To increase edible fish production, aquaculture is practiced in many parts of the world. However, parasites and diseases are the most serious limiting factors in aquaculture because of the increased density of cultured fish populations in restricted bodies of water and the ease by which pathogens can be transmitted from one fish to another (Kabata, 1985). These edible fishes are known to harbour a number of cestode parasites which cause deterioration in their health include emaciation (significant loss of body mass), nodules or masses present in skin or muscle, growth inhibition, abnormal swimming and weakness or death, hence their market and nutritive value is affected. Although, small numbers of cestodes may be found in fish without causing significant symptoms. Fish may be final host (containing adult cestodes) or intermediate host (containing larval cestodes). Parasite can have a wide range of impact on the ecology of their hosts in terms of health (Cumming et al., 2015). After acquiring infection, fish may perform certain types of simple or complex behaviour (Barber et al., 2000).

Assessment of infection levels in the host as well as host population provides important information about the success of the parasite life cycle, the severity of its pathogencity and the effectiveness of host immunity. As fish mostly constitute the final host it is extremely important to achieve early and correct diagnosis of the larval stages of the parasites for successful prevention and elimination of such infections. The current infection rates directly reflect successful parasitic invasion moderated by host defensive response and other behavioural influences such as competition (Bhure and Nanware, 2014). The study of population dynamics can be used as the biological basis of method to regulate population of parasites. Less work has been done on cestodes parasites of Channa species from Meerut (UP) region of India. Results of present study, 
therefore, are expected to be helpful for future research on piscian cestodes in this region. The present investigation deals with prevalence of three cestodes viz., Lytocestus sp., Proteocephalus sp. and Gangesia sp. from freshwater fish Channa punctatus, collected during annual cycle June, 2014 to May, 2015. Results of present study, therefore, are expected to be helpful for future research on piscian cestodes in this region.

\section{MATERIALS AND METHODS}

Study was conducted in different blocks of Meerut region viz: Hastinapur, Parikshitgarh, Sardhana, Sarurpur khurd, Daurala, Rohta, Jani, Rajpura, Macchra, Mawana and Kharkoda, Meerut. In the present study, intestines of Channa punctatus were examined for cestode infection during the period of June, 2014 to May, 2015 from Meerut region (U.P.) India, as shown in Fig. 1. Cestodes were collected, preserved in hot 4\% formalin, dehydrated in various alcoholic grades, stained with borax carmine, cleared in xylene and mounted in D.P.X. These Cestodes were identified by standard methods (Schmidt, 1986). The Cestodes collected were identified as Lytocestus sp., Proteocephalus sp. and Gangesia sp. Obtained data was recorded and studied for seasonal variation.

\section{RESULTS AND DISCUSSION}

The survey was carried out with 187 freshwater fishes, Channa puntatus, from various water bodies of Meerut region. Out of 187 freshwater fishes 104 were infected with cestode, as found in annual cycle from June 2014 to May 2015. Results of present study showing prevalence of piscean cestodes are presented in Table 01 . Three species of cestode parasites were recorded viz, Lytocestus sp., Proteocephalus sp. and Gangesia sp. It was found that, high incidence of infection of all these species were recorded in summer $(70.83 \%, 77.27 \%$ and $72 \%$ respectively) followed by winter $(63.63 \%$ abd $57.89 \%$ and $52.38 \%$ respectively) whereas infection was lowest in monsoon season $(36.84 \%, 27.78 \%$ abd $23.52 \%$ respectively) as shown in Fig 2.

The present results shows high incidence occurs in summer season followed by monsoon season where as low incidence were recorded in winter season. The valuable information pertaining to the influence of season on the cestode parasite was contributed by several workers. Bhure et al., 2010 noticed high prevalence $(51.78 \%)$ of Rhabdochona sp. from carp fish Labeo rohita in summer followed by winter and rainy season. High prevalence was recorded with high intensity and index of infection of Siluro taenia raoii in summer followed by winter whereas infection was lowest in monsoon (Bhure and Nanware, 2010). Borde and Jawale, 2012 reported high cestodes infection $(45.33 \%)$ from Clarias batrachus in summer season. Jadhav and Bhure, 2006 reported environmental conditions determine the general characters of the parasitic fauna and the health of host fishes. Bhure and Nanware
(2014) also reported high cestodes infection from Channa puntatus in summer season. These environmental variables include high temperature, low rainfall, sufficient moisture, water temperature, crowding that are necessary for development of parasite. High prevalence occurs in summer followed by other seasons (Sharma et al. 2010). Factors like temperature, humidity and rainfall, feeding habits of host, availability of infective host and parasite maturation are responsible for influencing the parasitic infections (Khan, 2012). The parasitic fauna, its composition, the incidence and intensity of infestations it produces, are largely determined by the host's mode of life and type of food (Kennedy, 1975 and 1976). Thus fishes were infected with large number of parasites in late winter to end of summer months, as ecological factors are favorable in these months (Pennyuick, 1973).

Similarly, plerocercoids of the fish tapeworm, Proteocephalus ambloplitis, avoid shedding from the intestine of its host by migrating into parenteral sites as the water temperature declines in winter, a period when feeding is reduced and worms voided because of a lack of nutrients, ( Fischer and Freeman 1973). However, the parasites reenter the intestine as the water temperature increases in spring to mature as adult tapeworms. The plerocercoid larva exploits host-derived energy to fuel its own growth from a microscopic larva to ca. 30 mg within ten weeks. Infected fishes (with plerocercoid cestode) apparently mount an immune response against the infection, evinced by the spleens of infected fishes, which increase in size (Taylor abd Hoole, 1994). In the periods of high reproductive investment (beginning of the breeding period or forming gonads after breeding), the fish are more susceptible to parasite infection. The cost is paid for reproduction by the fish due to immunosuppression by steroid hormones following the observation that spawning fish were more susceptible to parasite infection and had smaller spleen size in comparison with the resting fish (Viney et al., 2005). Immunity of fish is weakened when investing more extensively in spawning ornamentation, and is more parasitized (Wedekind C 1992).

The increase in cestode infection in spring supports the hypothesis that the parasite life cycle could by synchronized with the beginning of host reproduction, probably induced by increasing fish hormone levels in the spring (Simková et al., 2005). Changes in the fish feeding behavior and annual temperature regime have been considered as the principal factors responsible for the seasonal incidence and intensity pattern of parasites (Eure, 1976).

\section{Conclusion}

In the present study, recorded data showed high incidence of infection of all the cestode species in $C$. punctatus in summer followed by winter season where as low in monsoon season. The results suggest that $C$. 


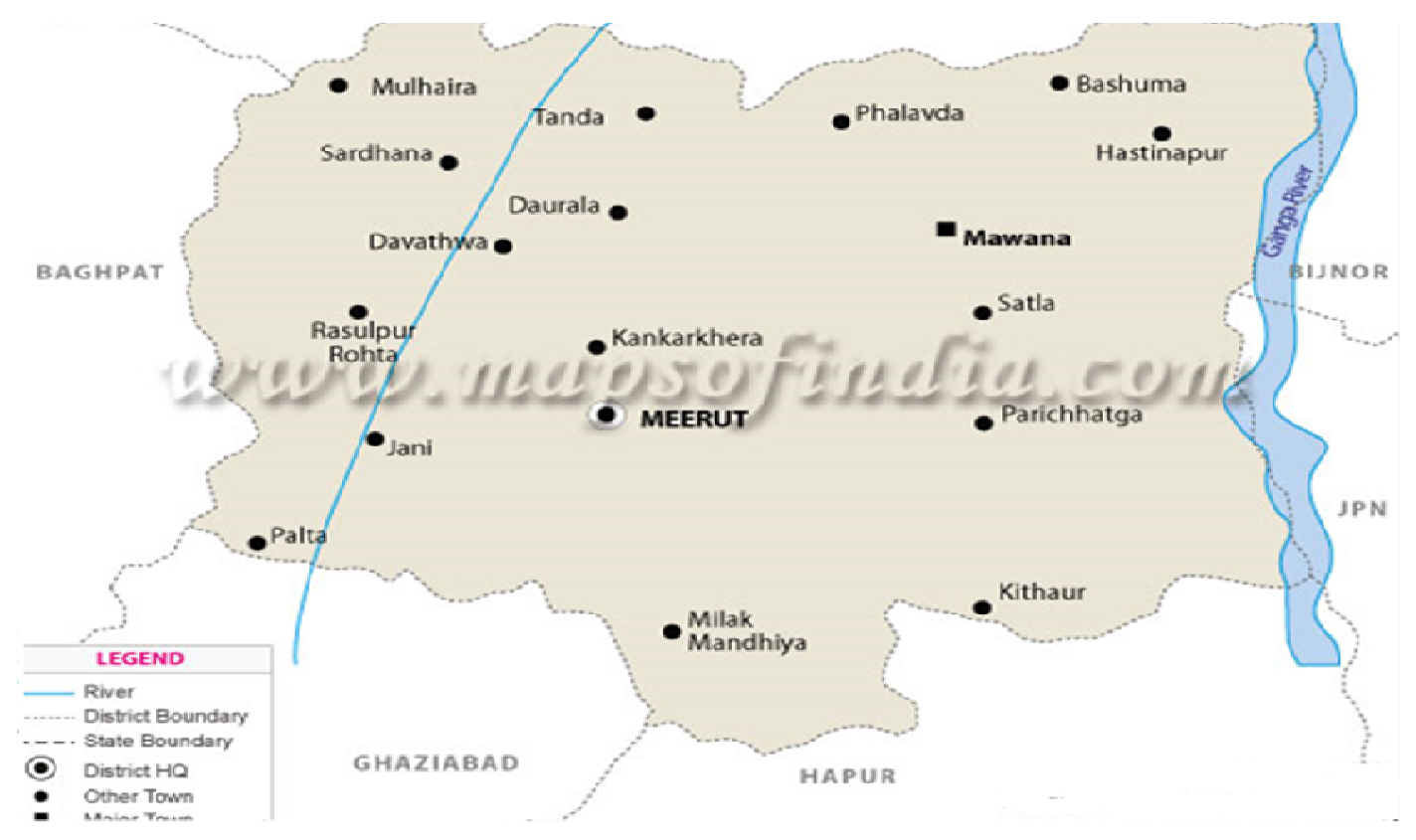

Fig 1. Map of Meerut showing 12 blocks from where fishes were collected.

Table 1. Seasonal variation of Lytocestus sp., Proteocephalus sp. and Gangesia sp in Channa punctatus during the period June 2014-Sept 2015.

\begin{tabular}{|c|c|c|c|c|}
\hline Parasitic sp. & $\begin{array}{l}\text { No. of the } \\
\text { host examined }\end{array}$ & $\begin{array}{l}\text { No. of the host } \\
\text { infected }\end{array}$ & $\begin{array}{l}\text { Total no. parasites } \\
\text { collected }\end{array}$ & Incidence \% \\
\hline \multicolumn{5}{|l|}{ Lytocestus sp. } \\
\hline Monsoon(June,2014-Sept2014) & 19 & 07 & 10 & $36.84 \%$ \\
\hline Winter (Oct 2014- Jan 2015) & 22 & 14 & 19 & $63.63 \%$ \\
\hline Summer,(Feb 2015-May 2015) & 24 & 17 & 20 & $70.83 \%$ \\
\hline \multicolumn{5}{|l|}{ Proteocephalus sp. } \\
\hline Monsoon(June2014- Sept2014) & 18 & 5 & 9 & $27.78 \%$ \\
\hline Winter (Oct.,2014- Jan., 2015) & 19 & 11 & 15 & $57.89 \%$ \\
\hline Summer,(Feb 2015-May,2015) & 22 & 17 & 18 & $77.27 \%$ \\
\hline \multicolumn{5}{|l|}{ Gangesia sp } \\
\hline Monsoon(June2014- Sept2014) & 17 & 4 & 8 & $23.52 \%$ \\
\hline Winter (Oct.,2014- Jan., 2015) & 21 & 11 & 11 & $52.38 \%$ \\
\hline Summer (Feb.2015-May,2015) & & 18 & 15 & $72.00 \%$ \\
\hline
\end{tabular}

puntatus fishes are more susceptible to cestodes parasitic infection in periods of higher reproductive investment. The differences in prevalence of incidence of parasitic infection is probably due to the immune function of fish compromised in stressful situation, including those that involve crowding and high temperatures. Climate change in aquatic systems mayl affect most organisms and their functional roles in the ecosystem. Changes in these roles may be difficult to detect, but examination of parasite communities in fish may provide insight into any structural and functional alterations in the system. Potential consequences of climate change are difficult enough to predict for free-living biological organisms. Given that parasites in aquatic systems depend on both the abiotic conditions of the environment and the distribution and abundance of their hosts for transmission, reproduction, survival, and other basic life-history functions, it is evident that pre- dicting the implications of climate change for parasites becomes increasingly complex and context dependent. It is likely that the direct impact of temperature change and indirect impact of changes in host biology will have significant ramifications for parasite populations in the aquatic environment.

\section{REFERENCES}

Barber, I., Hoare, D., and Krause, J. (2000). Effects of parasites on fish behaviour: a review and evolutionary perspective. Reviews in Fish Biology and Fisheries, 10(2), 131-165.

Bhure, D.B. abd Nanware. S.S., (2010). Population Dynamics of Silurotaenia raoii from Mystus seenghala. The Ecosphere (An International Biannual Journal of Environment and Biological Sciences). 2(1abd2):9-12.

Bhure, D.B., Nanware, S.S., Kardile, S.P., abd Dhondge, R.M. (2010). A survey of the population ecology of Rhabdochona Ralliet, 1916 (Nematoda- 
Rhabdochonidae) from Labeo rohita (Ham. and Buch.). The Ecosphere (An International Biannual Journal of Environment and Biological Sciences), 1(1) 12-24.

Borde, S.N., and Jawale, S.S. (2012). Population dynamics of caryophyllidean tapeworms in Clarias batrachus from Aurangabad district (MS) India. Trends in Parasitology Research, 1(1), 25-28.

Chakraborty, K. Vijayan, K.K., Vijayagopal, P., Mohanty, B.P. (2013). Marine Fishes in India: Their Importance in Health \& Nutrition , Issue 110 of Central Marine Fisheries Research Institute (CMFRI) Special Publication, Kochi, India

Cumming, D.H., Cumming, G.S., Zinsstag, J., Schelling, E., Waltner-Toews, D., Whittaker, M., abd Tanner, M. (2015). 4 One Health: an Ecological and Conservation Perspective. One Health: The Theory and Practice of Integrated Health Approaches, 38.

Eure, H. (1976). Seasonal abundance of Proteocephalus ambloplitis (Cestoidea: Proteocephalidea) from largemouth bass living in a heated reservoir. Parasitology, 73 (02), 205-212.

Haniffa, M.A., Marimuthu, K., Nagarajan, M., Arokiaraj, A.J. abd Kumar, D. (2004). Breeding Behaviour and Parental Care of the Induced Bred Spotted Murrel Channa punctatus under Captivity. Curr. Sci., 86 (10): 1375-1376.

Fischer, H., and Freeman, R.S. (1973). The role of plerocercoids in the biology of Proteocephalus ambloplitis (Cestoda) maturing in smallmouth bass. Canadian Journal of Zoology, 51(2): 133-141.

Jadhav, B.V., and Bhure, D.B. (2006). Population dynamics of helminth parasites in freshwater fishes from Marathwada region (MS) India. Flora and Fauna, 12: 143-148.

Kabata, Z. (1985). Parasites and diseases of fish cultured in the tropics. (1st edition). Taylor abd Francis, London and Philadelphia.

Kennedy, C.R. (1975). Ecological animal parasitology. Oxford, Blackwell Scientific Publications.

Kennedy, C.R. (1976). Ecological aspects of parasitology. North Holland publishing company Amsterdam Ox ford .
Molur, S. and Walker, S. (1998). Report of the workshop on "Conservation assessment and management plan (CAMP) for freshwater fishes of India”, Lucknow, 2226 Sept. 1997.

Pennyuick, K.L. (1973). Seasonal variation in the parasite population of three spined stickle backs. Gasterosteus aculeatus L. Parasitology, 63: 373-388.

Bhure. D.B. and Nanware. S.S. (2014) "Studies on prevalence of cestode parasites of freshwater fish, Channa punctatus. Journal of Entomology and Zoology Studies, 2 (4): 283-285

Khan, R.A. (2012). Host-parasite interactions in some fish species. Journal of Parasitology Research, http:// dx.doi.org/10.1155/2012/237280

Saikia, A.K., Abujam, S.K.S. and Biswas, S.P. (2012). Food and feeding habit of Channa punctatus (Bloch) from the paddy field of Sivasagar District, Assam. Bulletin of Environment, Pharmacology and Life Sciences, 1(5): 10-15.

Schmidt, G.D. (1986). CRC handbook of tapeworm identification. CRC Press, Inc.

Šimková, A., Jarkovský, J., Koubková, B., Baruš, V., abd Prokeš, M. (2005). Associations between fish reproductive cycle and the dynamics of metazoan parasite infection. Parasitology Research, 95 (1) : 65-72.

Sharma, B., Arora. N. and Singh. D.D. (2010) Population dynamics of Carryophyllid cestode Lytocestus Fossilisi (Gupta, 1961) from Clarias batrachus in Meerut (U.P). J.Env. Biosci, 24 (1) : 99-101.

Taylor, M. J., and Hoole, D. (1994). Modulation of fish lymphocyte proliferation by extracts and isolated proteinase inhibitors of Ligula intestinalis (Cestoda). Fish abd Shellfish Immunology, 4(3) : 221-230.

Viney, M.E., Riley, E.M., abd Buchanan, K.L. (2005). Optimal immune responses: immunocompetence revisited. Trends in Ecology and Evolution, 20(12) : 665-669.

Wedekind, C. (1992). Detailed information about parasites revealed by sexual ornamentation. Proceedings of the Royal Society of London B: Biological Sciences, 247 (1320) : 169-174. 